\title{
TEACHING SOCIAL ISSUES THROUGH CINEMA AND TELETANDEM
}

\section{Ensinando questões sociais por meio do cinema e do Teletandem}

\section{Aurora CASTILLO-SCOTT'1}

\begin{abstract}
Teletandem is an innovative learning experience that helps to connect foreign language students with native or competent speakers in a virtual context. Through a Teletandem project, students have the opportunity to learn a language while developing a new cultural dimension. This paper presents the pedagogical experience of using Spanish cinema and a U.S. - Chilean Teletandem project designed to promote linguistic skills while addressing sociocultural issues related to the target culture. Using Web 2.0 tools, students had monthly synchronous conversations that focused on cultural, racial, gender, and socialpolitical problems associated with the Hispanic culture. The Teletandem project allowed students to compare information learned in class with the material collected from their partners. This exchange of information helped students to form their own opinions and gain new perspectives of the target culture.
\end{abstract}

Keywords | Teletandem. Telecollaboration. Language learning. Social issues. Intercultural learning. Hispanic cinema.
Resumo | O Teletandem é uma experiência de aprendizado inovadora que ajuda a conectar estudantes estrangeiros com falantes nativos ou competentes em um contexto virtual. Através do projeto Teletandem, os alunos têm a oportunidade de aprender uma língua enquanto desenvolvem uma nova dimensão cultural. Este artigo apresenta a experiência pedagógica do uso do cinema espanhol e de um projeto norte-americano - Teletandem chileno, desenvolvido para promover habilidades linguísticas, ao mesmo tempo em que aborda questões socioculturais relacionadas à culturaalvo. Usando ferramentas da Web 2.0, os alunos tiveram conversas síncronas mensais focadas em problemas culturais, raciais, de gênero e sociopolíticos associados à cultura hispânica. O projeto Teletandem permitiu que os alunos comparassem as informações aprendidas em sala de aula com o material coletado de seus parceiros. Essa troca de informações ajudou os alunos a formar suas próprias opiniões e obter novas perspectivas da cultura-alvo.

Palavras-chave | Teletandem. Telecolaboração. Aprendizagem de línguas. Questões sociais. Aprendizagem intercultural. Cinema hispânico.

1 Castillo-Scott. GCSU. E-mail: aurora.castillo-scott@gcsu.edu. ORCID ID: https://orcid.org/0000-00021036-5260. 
- | Teaching social issues through cinema and teletandem

\section{Introduction}

In the last decade, technology has increased the opportunities to revolutionize the design and implementation of innovative language learning experiences. The classroom environment has transitioned from a passive and formal learning place into a dynamic area where students can experience real language learning practices. One of those authentic experiences is learning in-tandem. Vassallo and Telles (2006) stated that the growth of virtual learning settings has shortened the geographical barriers allowing people from different cultures to communicate while providing new forms of learning languages in-tandem. Regarding the definition of learning in-tandem, Little and Brammerts (1996) observed that it is a way of opening learning where learners of two different native languages mentor each other on their language skills, learn about their culture, and exchange information about their lives or professions.

There are three types of tandem learning: face-to-face tandem, e-tandem, and Teletandem. The contexts in which tandem learning happens and the language skills are developed in each mode are the foundation that differentiates the kinds of tandem. In face-to-face tandem, learners share the same physical space and develop all four-language skills through different practices. In e-tandem, learners use their own digital space, which can be an email or a chat environment. The skills used in this tandem learning type are reading and writing with no practice of speaking and listening skills (TELLES; VASALLO, 2006).

The third type of in-tandem learning is Teletandem, a virtual Tandem communication context that is performed through digital technologies such as Skype, Google Hangouts, or Zoom and offers text, audio, and video resources. Telles (2015) explains that Teletandem is another way of telecollaboration for language learning based on a virtual, collaborative and autonomous environment. In this learning experience, students learn and mentor each other on their language acquisition process following three main principles: autonomy, reciprocity, and separation of languages (BRAMMERTS, 2003; TELLES; VASALLO, 2006). There are different ways of implementing Teletandem in the course curriculum: institutionally, institutionally non-integrated and institutionally integrated (ARANHA; CAVALARI, 2014; TELLES, 2015). A correctly implemented institutionally integrated Teletandem should include elements such as preparation of students and integration of tasks and assessment tools in the course curriculum (CAVALARI; ARANHA, 2016).

In this article, the author will focus on the implementation of institutionally integrated Teletandem in the language classroom as a means to address social issues of the 
target culture. To achieve this goal, the instructor of the course incorporated three main elements: Spanish cinema, institutionally integrated Teletandem, and social issues. In the following sections, the author will describe the pedagogical experience of combining and using these three techniques in a language conversation course.

\section{Teletandem and Language Learning}

When talking about Teletandem, it is essential to review some of the benefits of using this learning technique in language acquisition. One element that is positively affected during a session is feedback. Consolo and Furtoso (2015) demonstrated that the feedback offered during the session is essential to give context, maintain the progress of interaction, and provide support to acknowledge the interlocutor's speech. When writing and giving peer feedback, students focus on language form when correcting their partners' written production using their beliefs and experiences as learners (ARANHA; CAVALARI, 2015).

Teletandem is also considered an environment that increases independence and responsibility among students and teachers. It also promotes critical analysis and awareness of both student and partner's language and culture (CARVALHO; MESSIAS; DÍAS, 2015). It is also important to point out that using real language in context in a Teletandem session helps to promote the process of teaching-learning languages and decreases the space barrier among language learners (RAMOS, 2015).

Regarding culture learning, Teletandem makes it possible to experience real culture, to break stereotypes, and to acquire a more flexible and personal view of the target culture (SALOMÃO, 2015). Learning culture in-tandem gives the opportunity of being confronted with several forms of acting and thinking. It also allows learning new elements of the target culture and comparing the cultural similarities in those elements (SANTOS, 2015). Essentially, Teletandem offers learners the opportunity to become aware of the world's cultural differences giving them a variety of sources of knowledge and increasing learners L2 intercultural communicative competence (AL HASNAWI, 2013). Al Hasnawi also explains that there are other factors such as collaboratively well-trained instructors, correct selection of topics, appropriate participants, and the right tools that influence intercultural competence. 
- | Teaching social issues through cinema and teletandem

\title{
Discussing Social Issues in Language Learning
}

Language teachers' responsibilities have increased in the last ten years, moving from teaching language content and developing language skills into more complex and more significant tasks. Pratama (2016, p. 719) states that

\begin{abstract}
[...] we as educators should also pay attention to some problems occurring in the world and equip our students with knowledge and skills to actively participate in solving the problems or at least showing sympathy to those issues. It is morally far from good to only stick our mind in teaching the textbooks we are using without any care for the problems around us.
\end{abstract}

With that idea in mind and with the goal of exposing language students to some of the global issues in our societies, the UNESCO's Linguapax ${ }^{2}$ program has developed a list of recommendations to language educators. One of the recommendations focuses on the implementation of international understanding in the language teaching and learning process with the goal of creating cooperation among countries. Another advice emphasizes the importance of promoting students' collaboration in the language classroom to develop an international partnership among nations. The program also suggests the use of extracurricular activities and resources such as videos, exchange programs, and activities to create international understanding (UNESCO, 1987).

Recent studies have demonstrated that the use of social justice-oriented practices gives students a foundation for their future professional settings. Students are better prepared to actively participate in a multicultural and multilingual society when exposed to such methods (DA CRUZ, 2017). Students who gain exposure to global education develop social responsibility that makes them better participants of the world (PRATAMA, 2016). It also promotes global awareness among students helping them to gain a better understanding of international issues and sparks an interest to contribute to a better world (KIP, 2005).

Although there is a strong rationale to why language instructors should integrate social issues in the language classroom, incorporating such cultural topics is seen as a problematic and complicated challenge (TEDICK; WALKER, 1994). Nevertheless, many

2 Linguapax is an organization founded by UNESCO that focuses on the protection and revitalization of languages to promote peace. 
instructors around the world have created cultural projects to promote intercultural learning and integrate social issues in language learning. As described by Kern (2006), cross-cultural projects are essential pedagogical approaches that can help to increase students' cultural knowledge and offer a setting to view students' culture from their peer's perspective. Even more critical, like Kubota, Austin, and Saito-Abbott (2003, p. 22) stated, is that "[...] by using community and technology resources, teachers and learners can begin to discuss socio-political issues underlying their diverse life experiences and call into question our commons assumptions about culture and society". With all these ideas in mind, the author of this article has designed and implemented an intercultural project that combines Teletandem learning, Spanish cinema, and social issues. In the following sections, the author will describe the project, its different stages and elements, and will mention her reflections based on her own experiences.

\section{Description of the Project}

The instructor implemented the project in Fall 2016 and carried it out for two consecutive Fall semesters. Unfortunately, it was not possible to incorporate the project during Spring semesters because of schedule differences between the U.S. college and the partner university in Chile. In Fall 2016, 15 students participated from each group, and in Fall 2017, 33 students from each group were involved in the project. Students from the U.S. group were English native or competent speakers majoring and minoring in Spanish, and students from the Chilean group were Spanish native or competent speakers mostly majoring in science and engineering fields. Students from the U.S. group were enrolled in an intermediate/mid-level (ACTFL ${ }^{3}$ PROFICIENCY GUIDELINES, 2012) Spanish Conversation, and Diction course and the Chilean students were taking a B1 level (EUROPEAN UNION COUNCIL RESOLUTION, 2001) Communicative English course.

When describing students' gender and race, it is possible to say that diversity played an important role in the American group. Both groups (Fall 2016-2017) were very diverse with the participation of Hispanic students, Spanish heritage students, African American students, LGBTQ ${ }^{4}$ students, and white students. On the contrary, most of the students in the Chilean group were Hispanic, white males with few females and one Jamaican student. Students' age in both groups ranged from 18 to 23 years old. It is important to point out that the U.S. group studies at a public Liberal Art College and the Chilean group studies at a traditional private research university.

3 ACTFL is the American Council on the Teaching of Foreign Languages that works to improve and promote language teaching and learning across all levels.

4 LGBTQ are the initials that stand for lesbian, gay, bisexual, transgender and queer communities. 
- | Teaching social issues through cinema and teletandem

Regarding the technology used in the project, the instructors of both universities initially selected the same online communication tools used by them in a previous project (CASTILLO-SCOTT, 2015). In that opportunity, the students used Skype and Google Hangouts tools to communicate. The instructors decided to use the same online communication tools because of students' familiarity with these Web 2.0 tools. Both instructors required students to video record the sessions of this project. For that reason, the instructors suggested video recording tools such as Quick Time and CallNote. However, some students experienced difficulties with those programs because of either compatibility issues (Mac vs. PCs) or having to pay extra cost to download the applications on their computers. Some students looked for other alternatives to avoid the additional cost, and they used their cell phones to record the sessions. Unfortunately, the sound and quality of the video was weak, which made it difficult for the instructor when reviewing and grading the sessions. For all those reasons, some students started using Zoom, a free online communication tool that facilitates the communication while recording the conversation. Zoom is a video conferencing service using Cloud computing. It offers many capabilities such as screen sharing and documents, chat, and video recording conversations. The video conversations used an mp4 format that facilitates saving space and uploading the material into a Learning Management System (LMS). As the instructor of this project, the author suggests using just one single program to avoid confusion among students and receiving a different type of formats and video recordings.

With respect to students session's submissions, the instructor used the college LMS where students could upload and store their video recordings. The differences in students' video formats slowed the uploading process in the LMS. In order to solve this issue, the instructor asked students to upload videos to YouTube or Vimeo and share their links through the LMS.

All the session in this Teletandem project followed the three main Tandem principles: separation of languages reciprocity, and autonomy (VASSALLO; TELLES, 2006). The instructors asked students to complete four sessions in one semester. Each session was scheduled once a month and lasted sixty minutes. Following the separation of languages principle, each session dedicated thirty minutes to each language - English or Spanish - for a total of one hour. To guarantee that students followed this principle, instructors requested that they would record the video sessions. Each video recording should include thirty minutes in each language. All the meetings were held outside the classroom during students' own time to achieve the principle of autonomy. Students had to schedule the date and time they wanted to complete their sessions. 
By assigning specific talking points (see Table 1 and Appendix A), it was possible to attain the principle of reciprocity. Both groups had their own set of topics that reflected their course goals and material. During the session, students had to discuss their talking points giving time to their partners to address the one assigned to them.

Selecting the topics for each session was one of the critical elements of the Teletandem project. Because the course goals and material were different for both groups, each group had its own set of topics. The instructor in the Chilean group decided to continue with the topics already used in a previous Teletandem project (CASTILLOSCOTT, 2015). On the contrary, the instructor in the Spanish group selected social issues topics addressed in some of the movies included in the course textbook Cinema for Spanish Conversation (GILL; SMALLEY; HARO, 2014). The textbook has a total of 12 films and the instructor selected only nine movies for the semester because of time constrains. The instructor also tried to choose movies that represented different Hispanic countries (e.g., No-Chile; Even the rain - Bolivia). The films that were selected for the course were Under the same moon, Tear this heart out, María full of grace, Even the rain, The motorcycle diaries, No, Flowers from another world, All about my mother and The sea inside.

Then, the instructor selected the social issues of the movies Under the same moon, Tear this heart out, and María full of grace for the discussions in the Teletandem sessions. Under the same moon talks about illegal immigration in the United States and the struggles of illegal immigrants when crossing the border and living in the U.S., Tear this heart out discusses dictatorship, abuse of power and domestic violence, and María full of grace addresses the socio-economical crisis and battles that lead Colombian women to become involved in narcotrafficking.

To reflect the movies' social issues and to help students gain a better understanding of how those issues can be different in each Latin-American culture, the instructor asked students to focus on the issue from their partners' perception. The instructor also asked students to compare the issues in their own culture and their partners' culture. Table 1 shows the topics for each session and its social perspective. 
- | Teaching social issues through cinema and teletandem

Table 1. Sessions' Topics

\begin{tabular}{lllll}
\hline Session & First & Second & Third & Fourth \\
\hline Topic 1 & Immigration in & Machismo and & Narco-trafficking & Open \\
& Latin America & gender violence & in Latin America & topic \\
& and Chile. & in Chile. Compare & and Chile. & \\
& Compare & machismo and & Compare narco- & \\
& immigration & gender violence in & trafficking in Chile & \\
& in Chile versus & Chile versus in the & versus in the & \\
& in the United & United States. & United States. & \\
& States & & & \\
\hline Topic 2 & Select one or & Select one or & Select one or & Open \\
& more items from & more items from & more items from & topic \\
& the Suggested & the Suggested & the Suggested & \\
& Topics list. & Topics list. & Topics list. & \\
\hline
\end{tabular}

There was a total of four meetings with only three focusing on social issues. The fourth session had an open topic. In this last session, students could talk about any talking point they wanted. They had to negotiate the items they were interested in with their partners. To make the session topics exciting and not too repetitive, the instructor asked students to spend the first 15 minutes of the session discussing the social issue. Then, students could transition to other topics related to cultural aspects. For that reason, the instructor added a list of suggested items. Some of the proposed cultural issues were music, art, food, traveling, the life of a college student (Chile vs. the U.S.A.), traditions and festivities among the others.

\section{Integrating the Teletandem Project in the Course}

In this section, the author focuses on how to incorporate the Teletandem project in the course curriculum connecting class activities, textbook information, Spanish movies, social issues, and the project. To better explain the integration process, the author has divided the material into two groups: in-class and out of class activities.

The in-class activities started with the selection of some of the course textbook's exercises to introduce the Spanish movies and the social issue at hand. First, the instructor 
presented the film, its main characters and the director through textbook readings, movie title discussion, and comprehension questions. Continuing with the textbook resources, the students completed vocabulary, storyline, and conversation question activities. During these practices, students identified some of the social issues addressed in the movies. Then, the instructor brought additional material such as newspapers' readings, songs, poems or short documentaries.

The students lead the last in-class activity. At the beginning of the semester and working in pairs, students selected one of the movies to lead a discussion. During this movie discussion, students addressed specific facts of the storyline and debated about the movie social issue(s). To conduct the debate, students had to research facts about the movie and the social aspect (s). Some of the research resources were the Internet, events in the film, own cultural experience, newspaper readings, and material from other courses.

In many of the discussions, students used their background knowledge, research, and own cultural experiences. For that reason, on some occasions, some conversations seemed biased without demonstrating critical analysis or target's culture point of view. As a consequence, the Teletandem project main goal was to help students to learn about specific social issues from the Spanish native speaker's perspective and cultural experience. This practice helped students to build a stronger foundation of social problems and open their eyes to the reality of the target culture.

The instructor organized the out-of-class activities in three different steps: review and select topics, prepare an outline or questions, and complete Teletandem sessions. In the first step, students reviewed the central theme stated in the Teletandem Guidelines (see Appendix A). They looked for the information the instructor wanted them to collect from their Chilean partner. Students had to create a list of some of the Additional Topics they wished to discuss adding any topic of their interest.

In the second step, using the primary and additional topics, students prepared an outline ordering the themes based on its relevance and interest. Students also wrote a set of questions for each item. These techniques helped students to maintain an organized conversation and keep track of the topics they have discussed.

Completing the Teletandem session is the last step. As explained before, students met in their date and time using the Web 2.0 tool of their preference. During the meeting, students discussed the topics selected for the session for both groups.

Integrating a Teletandem project in a course curriculum is not a daunting and complicated process. It requires planning and carefully structuring all the stages of the 
- | Teaching social issues through cinema and teletandem

project. For that reason, in the following section, the author explains in detail all the steps, elements, and circumstances that should be taken into consideration when creating a Teletandem project.

It is necessary to follow an organized structure when implementing a Teletandem project. Therefore, the instructors divided the project in a set of steps. For the first stage, both instructors collected all the information about students participating in both groups: the number of students in each group, majors or minors, and emails. The instructors had to identify if international students were participating in the project. This practice was necessary because most students expected to interact with a native speaker. For that reason, the instructors had to inform some students that their partners were not English or Spanish native speakers but $\mathrm{s} /$ he was a competent speaker of the target language. In this project, only two students from both groups were not English and Spanish native speakers. In this first stage, the instructors also selected the date of the session. They integrated all meetings into the syllabus following their course schedules. The instructor in the Spanish group also connected the movies, the social issues, and the Teletandem sessions.

After their participation had been confirmed, learners on the U.S. and the Chilean sides were assigned to pairs based on their similar fields of study (i.e. majors, such as for instance engineering). Then the instructor grouped the still unassigned U.S. students with Chilean partners in related fields suggested by the U.S. students' minors. Finally the third group included students who did not share any similarities in their areas of study. In sum, learners worked in groups that reflected as much as possible their shared disciplinary interests.

In the second stage, the instructor handed the guidelines (see Appendix A), explained the project, topics and due dates for each session, assigned students' partners, explained grading criteria, suggested online programs to be used (Skype and Google Hangouts), described the screen video recording programs and explained uploading procedures in the LMS. At this point, the instructor clarified students' questions and received students' input regarding the additional cultural topics they wanted to add.

The third stage focused on students establishing first contact and instructors keeping track of the students who were not responding to their partners. For that reason, instructors asked students to copy them when sending the first email to their partners. This practice helped instructors to keep track of students who were late on establishing the first contact, who were not communicating with their partners, or who did not set up the date for the first session. Constant communication between the instructors was equally important. They sent emails to students who were getting behind and who had dropped out from the course. 
The fourth stage was students' sessions and submission of video recording sessions in the LMS by the due date. Instructors in both groups asked students to report in class on their experiences in each meeting and to provide some feedback. Lastly, instructors discussed students' received feedback, commented on any issues and made necessary changes.

\section{Assessment}

There are many ways to assess a Teletandem project. As a general rule, in an institutionally integrated Teletandem, the outcomes of the project, tasks and course goals should connect directly to the assessment techniques (CAVALARI; ARANHA, 2016). In this Teletandem project, the instructor used two different assessment techniques. In the Fall 2016 project, both instructors used the same assessment approach. As explained before, both instructors asked students to record the 60-minute sessions and upload the video recordings to the LMS. In addition to this video recording, students had to record a self-video summary of the project at the end of the semester. They had to describe what they had learned from their partners during each session. Students in the Spanish group had to talk about each social issue, mention what they had learned from their partner, and compare it with their own culture. The Spanish instructor also requested students to give their feedback and suggestions on the project. This last self-video provided valuable information about the project. Students questioned the validity of having two different assessment techniques that were quite similar. They thought that the final video was repetitive and it had not given any extra value to the project.

Based on students' feedback, for the second semester of the project, the instructor decided to focus on just one assessment technique. For that reason, in Fall 2017, the Spanish instructor requested only the 60-minute video recordings of each session. At the end of the semester, students should have four 60-minute video recordings uploaded in the LMS. The instructor evaluated the videos focusing on the 30 minutes in which students had used the target language. Equally, the instructor asked students to share in-class their experiences in the sessions. Students talked about what they had learned from their partner about the social issue. They also included the additional topics discussed during that session. The instructor designed a rubric to evaluate students' videos. The criteria focused on students' intercultural competence, the content of the session, reciprocity between students, and students' linguistic discourse. 
- | Teaching social issues through cinema and teletandem

\section{Instructor's Reflections}

The instructor based her reflections on two different aspects: students' attitude towards discussing social issues in Teletandem and difficulties experienced during the project.

Regarding students' attitude, it is possible to say that students in the U.S. group have very few opportunities to interact with Spanish native speakers. The college is geographically located in a rural area in the Southeast of the country, which makes it difficult to expose students to Spanish native speakers. For this reason, students found the Teletandem project to be an excellent opportunity to speak with native speakers of the target culture and collaborate with each other mentoring on their oral language skills. Most students thought that the project was beneficial and a useful language-learning technique.

As explained in the $5 \mathrm{C}^{\prime} \mathrm{s}^{5}$ of the National Standards for Foreign Language Learning (1996), students can develop a better understanding of the studied culture when they investigate, explain, and reflect on the other culture and their own. Consequently, learners are more open to understanding the target culture's issues, as well as native speakers' opinions and perspectives. In this project, students were able to compare their previous knowledge on the social problems, their own culture's point of view with their partners' point of view. As a result, students realized that discussing social issues in a Teletandem project helped them to gain a better understanding of the target culture's social problems.

Before the beginning of the project, students expressed their concerns about the complexity level of the selected topics. Some students had doubts about their ability to reflect and explain social issues to a Spanish native speaker. However, by the end of the project, many students found that discussing social issues in a Teletandem project was not as complicated as they had initially thought. The instructor based this positive response on the proper integration of the Teletandem project into the course curriculum (ARANHA; CAVALARI, 2014; CAVALARI; ARANHA, 2016; O'DOWD, 2007; TELLES, 2015), and the correct in-class preparation of students before each Teletandem session (CAVALARI; ARANHA, 2016).

Another aspect that the instructor had to reflect on was students' topics preferences. As it was mentioned before, each session had a specific social issue plus an additional open topic (see Table 1). Although there were only three social issues, students were specific on their choices of preference: immigration and machismo/gender violence.

5 ACTFL 5 C's are the World-Readiness Standards for Learning Languages. They are divided in Communication, Culture, Connections, Communities and Comparisons. 
Students' comments demonstrated that the current socio-political environment in their culture profoundly influenced those choices. They also reported being more exposed to those specific social issues through media or other courses they had taken before.

Another observation made by the instructor is that students seemed intimidated or uncomfortable to openly express their opinions and points of view when discussing social issues in class. On the contrary, when reviewing students' video recordings, the instructor could easily identify how comfortable students felt about expressing their opinions and political points of view with their partners. Students have more in-depth conversations openly discussing their ideas and opinions. They also demonstrated becoming more aware of the similarities and differences of socio-political issues and movements in both countries (e.g., \#MeToo versus \#NiUnaMenos movements ${ }^{6}$ ).

\section{Difficulties Experienced}

As in any other pedagogical project, it is necessary to recognize the challenges experienced during the project. Identifying those problems will help to improve the planning, integration, and future projects execution. One of the first problems found was how the use of different online programs brought confusion among students. Some students did not have experience recording video sessions, downloading programs to their computers or uploading video recordings in the LMS. To solve those issues and aiming at lowering students' anxiety, the instructor gave constant support installing programs on their computers. She looked for other options when students' computers were not available or suggested other options when uploading video recording in the LMS (YouTube or Vimeo). When working with technology and online programs, it is essential to keep in mind that even though millennials have grown up using technology, they are not experts in solving technical difficulties.

There were other difficulties students experienced regarding their interactions with their partners. Some of those difficulties were students not responding to emails, dropping the course, or not completing Teletandem sessions. As mentioned before, reciprocity is one of the principles of Teletandem (VASSALLO; TELLES, 2006). For that reason, students' accountability is critical during the execution of the project. If a student does not respond to emails or forgets to attend the session without any previous notification, his/her partner's motivation will be affected by losing interest in the project. One more important aspect is a student unexpectedly dropping the course, which leaves a student without a

6 \#MeToo is the movement to help survivors of sexual violence in the United States and \#NiunaMenos is a movement that has risen up against violence towards women in LatinAmerica. 
- | Teaching social issues through cinema and teletandem

partner. To solve this issue, instructors should allow the student to work with another pair (group of three students) or find a target language native speaker in their community who is willing to work with that particular student.

In order to have a successful Teletandem project, both instructors need to keep track of students' performance, attendance, completion, and submission of assignments. Instructors have to promptly communicate with students when they do not submit the video by the due date or when their partners do not respond to emails. It is also critical that both instructors keep communicating with each other to solve any unexpected problem and to control the correct execution of the Teletandem project.

There are two more essential elements related to difficulties experienced: students' lack of vocabulary knowledge about social issues and the differences in groups' topics. As mentioned before, the In-class Activities section provided students with a vocabulary that was present in the movies they watched. The vocabulary practice included cognates, verbs, colloquial expressions, and words related to specific aspects of the film. Even though the In-class Activities should have prepared students with enough vocabulary to use in the discussion, few students felt they lacked the vocabulary to master the social issue discussion. Some students reported that their partners used advanced vocabulary and unknown Chilean expressions during the sessions. For that reason, some students struggled with comprehending their partner and the issue at hand. Students also mentioned they had to spend more time preparing and searching for some vocabulary before each conversation. As a result, some students thought it was overwhelming and time-consuming preparing their material for the Teletandem session.

With the idea of increasing students' vocabulary and giving students more tools to better perform in the Teletandem sessions, the instructor suggests adding a list of vocabulary words related explicitly to each social issue. Equally, the instructor recommends asking the instructor of the partner group for a list of the most used colloquial expressions in the target culture. The Spanish instructor can design and incorporate in-class activities using both lists of vocabulary and idiomatic expressions into the project.

In regards to differences in groups' topics, few students seemed unhappy with the difference between the topics for both groups. As explained above, the Chilean's group instructor decided to use the same topics she had used in a previous Teletandem project (CASTILLO-SCOTT, 2015). Those topics aligned better with her course goals and materials. For that reason, she did not want to make the change into new topics or explore discussing social issues. Therefore, some students thought that the Chilean group's topics were less complex than the U.S. group. 
Consequently, few students felt their expectations were higher and more difficult to achieve. To avoid a feeling of unfairness among students, it is vital that the instructor reminds students of the learning goals before each session, prepare students well before meetings, have additional open topics for students to choose on, and be more flexible with the outcomes of sessions and when grading students' video recordings. Lastly, the instructor may also look for other partner-instructors interested in integrating social issues discussions into their course curriculum with the goal of creating a new Teletandem project.

\section{Conclusions}

This paper described the pedagogical experience of a Teletandem project that helps to improve students' linguistic skills while discussing social issues of both their own culture and the target culture. In this learning experience, students had monthly Teletandem sessions in which they discussed social problems with native or competent speakers of the target culture. Students developed not only their linguistics skills but expanded their intercultural competence. As in any other Teletandem project, students thought that Teletandem is a useful language learning technique that helps to improve their confidence when interacting with native or competent speakers of the target language. It also allows learners to mentor each other while being exposed to a wide range of knowledge ( $\mathrm{AL}$ HASNAWI, 2013).

When the instructor properly integrates a Teletandem project into the course curriculum and prepares learners well before their sessions, Teletandem can be a viable pedagogical strategy that allows students to gain a better understanding of social-political issues of the target culture, increase students' intercultural competence, and openly express opinions without a sense of intimidation.

There were a few valuable lessons learned during this Teletandem learning experience. Instructors and students constant communication and feedback allowed adjusting some issues that could affect the project. Other issues were more difficult to control, but instructors' flexibility helped students to have a fruitful and vital learning experience. Lessons learned in this project provided valuable information for the appropriate integration of more social issues, cinema and Teletandem projects in the language-learning curriculum. The lessons also raised relevant issues and questions that are worthy studying in future research investigations. 
- | Teaching social issues through cinema and teletandem

\section{References}

AL HASNAWI, S. B. Intercultural Communicative Competence Development In Teletandem Learning Context, 2013, June. Paper presented at The Sixth Conference of MIT's Learning International Network Consortium. Available in: http://linc. mit. edu/ linc2013/proceedings/Session4/Session4AlHasnawi.pdf. Access: 18 jun. 2018.

AMERICAN COUNCIL ON THE TEACHING OF FOREIGN LANGUAGES. ACTFL Proficiency Guidelines 2012, 2012. Available in: http://www.actflorg/sites/default/files/pdfs/ public/ACTFLProficiencyGuidelines2012_FINAL.pdf. Access: 05 jun. 2018.

ARANHA, S.; CAVALARI, S. M. S. A trajetória do projeto Teletandem Brasil: da modalidade institucional não-integrada à institucional integrada. The ESPecialist, v. 35, n. 2, p. 183201, 2014. Available in: https://repositorio.unesp.br/bitstream/handle/11449/122298/ ISSN0102-7077-2014-35-02-70-88. pdf? sequence=1\&isAllowed=y 2014. Access: 16 jun. 2018.

ARANHA, S.; CAVALARI, S. M. S. Institutional Integrated Teletandem: What have we been learning about writing and peer feedback? DELTA: Documentação de Estudos em Lingüística Teórica e Aplicada, v. 31, n. 3, p. 763-780, 2015.

BRAMMERTS, H. Autonomous language learning in tandem: The development of a concept. In: LEWIS, T.; WALKER, L. (ed.). Autonomous language learning in tandem. Sheffield, Uk: Academy Electronic Publications, 2003. p. 27-36.

CARVALHO, K. C. H. P. D.; MESSIAS, R. A. L.; DÍAS, A. M. Teletandem within the Context of closely-related languages: a Portuguese-Spanish interinstitutional experience. DELTA: Documentação de Estudos em Lingüística Teórica e Aplicada, v.31, n. 3, p. 711-728, 2015. Available in: http://www.scielo.br/pdf/delta/v31n3/1678-460X-delta-31-03-00711.pdf. Access: 18 jun. 2018.

CASTILLO-SCOTT, A. Pan-American teletandem language exchange project. The EuroCALL Review, v. 23, n. 1, p. 36-40. Universitat Politècnica de València, 2015.

CAVALARI, S. M. S.; ARANHA, S. Teletandem: integrating e-learning into the foreign language classroom. Acta Scientiarum. Language and Culture, v. 38, n. 4, p. 327-336, 2016. 
CONSOLO, D. A.; FURTOSO, V. B. Assessing oral proficiency in computer-assisted foreign language learning: A study in the context of teletandem interactions. DELTA: Documentação de Estudos em Lingüística Teórica e Aplicada, v. 31, n. 3, p. 665-689, 2015. Available in: http://www.scielo.br/pdf/delta/v31n3/1678-460X-delta-31-03-00665.pdf. Access: 18 jun. 2018.

COUNCIL OF EUROPE. Common European Framework of Reference for Languages, 2001. Available in: http://www.coe.int/t/dg4/linguistic/Source/Framework_EN.pdf. Access: 21 jun. 2018.

DA CRUZ, Z. J. Social Justice-oriented Teaching in the English Language Classroom: Perspectives and Practices. 2017. M. Ed. Thesis (Teaching in Upper-Secondary School) -Faculty of Teacher Education, School of Education University of Iceland, 2017. Available in: https://skemman.is/handle/1946/28617. Access: 26 aug. 2018.

GILL, M. M.; SMALLEY, D.; HARO, M. P. Cinema for Spanish conversation. 4. ed. Hackett Publishing, 2014.

KERN, R. Perspectives on technology in learning and teaching languages. Tesol Quarterly, v. 40, n. 1, p. 183-210, 2006.

KIP, A. C. Teaching for a better world: Global issues and language education. Human Rights Education in Asian Schools, v. 8, p. 41-52, 2005.

KUBOTA, R.; AUSTIN, T.; SAITO-ABBOTT, Y. Diversity and inclusion of sociopolitical issues in foreign language classrooms: An exploratory survey. Foreign Language Annals, v. 36, n. 1, p. 12-24, 2003.

LITTLE, D.; BRAMMERTS, H. A guide to language learning in Tandem via the Internet. CLCS Occasional Paper n. 46, Trinity College, Centre for Language and Communication Studies, Dublin, IR, 1996.

NATIONAL STANDARDS IN FOREIGN LANGUAGE EDUCATION PROJECT, Yonkers, NY. Standards for foreign language learning: Preparing for the 21st century. ERIC Clearinghouse, 1996.

O'DOWD, R. Evaluating the outcomes of online intercultural exchange. ELT Journal, v. 61, n. 2, p. 144-152, 2007. 
- | Teaching social issues through cinema and teletandem

PRATAMA, H. Global Education in English Classroom: Integrating Global Issues into English Language Teaching. International Journal of Social Science and Humanity, v. 6, n. 9, p. 719-722, 2016.

RAMOS, K. A. H. P. Interactants' beliefs in teletandem: Implications for the teaching of Portuguese as a foreign language. DELTA: Documentacão de Estudos em Lingüistica Teórica e Aplicada, v. 31, n. 3, p. 691-709, 2015. Available in: http://dx.doi.org/10.1590/01024450360261275238411. Access: 18 jun. 2018.

SALOMÃO, A. C. B. Teletandem and telepresence: Rethinking the cultural component in language teaching and language teacher education. DELTA: Documentação de Estudos em Lingüística Teórica e Aplicada, v. 31, n. 3, p. 781-800, 2015.

SANTOS, L. Teletandem between French and Brazilian students: Some preliminary remarks. DELTA: Documentacão de Estudos em Lingüistica Teórica e Aplicada, v. 31, n. 3, p. 801-823, 2015. Available in: http://www.scielo.br/pdf/delta/v31n3/1678-460X-delta-31-03-00801. pdf. Access: 18 jun. 2018.

TEDICK, D. J.; WALKER, C. L. Second language teacher education: The problems that plague us. The Modern Language Journal, v. 78, n. 3, p. 300-312, 1994.

TELLES, J. A. Learning foreign languages in teletandem: Resources and strategies. DELTA: Documentação de Estudos em Lingüística Teórica e Aplicada, v. 31, n. 3, p. 603-632, 2015. Available in: http://www.scielo.br/pdf/delta/v31n3/1678-460X-delta-31-03-00603.pdf. Access: 24 aug. 2018.

TELLES, J. A.; VASSALLO, M. L. Foreign Language Learning in-tandem: Teletandem as an alternative proposal in CALLT1. Aprendizagem de Línguas In-Tandem: Teletandem como uma Proposta Alternativa em CALLT. The ESPecialist, v. 27, n. 2, p. 189-212, 2006. Available in: $\quad$ https://www.researchgate.net/profile/Joao_Telles/publication/277054748_ Aprendizagem_de_Linguas_InTandem_Teletandem_como_uma_Proposta_Alternativa_ em_CALLT/links/55d390f908ae0a3417226ab5.pdf. Access: 13 aug. 2018.

UNESCO, Linguapax Kiev Declaration on "Content and Methods that could Contribute in the Teaching of Foreign Languages and Literacy to International Understanding and Peace." Paris: UNESCO, 1987. 
VASALLO, M. L.; TELLES, J. A. Foreign language learning In-Tandem. Theoretical Principles and Research Perspectives. The ESPecialist, v. 25, n. 1, p. 1-37, 2006. Available in: http:// www.teletandembrasil.org/site/docs/Tandem_Part_I_The_Specialist_Revised_10_ identified.pdf. Access: 03 oct. 2018.

COMO CITAR ESTEARTIGO: CASTILLO-SCOTT, Aurora. Teaching social issues through cinema and teletandem. Revista do GEL, v. 15, n. 3, p. 257-278, 2018. Disponível em: https://revistadogel.gel.org.br/

DOI: http://dx.doi.org/10.21165/gel.v15i3.2409

Submetido em: 14/11/2018 | Aceito em: 21/12/2018. 
- | Teaching social issues through cinema and teletandem

Appendix A

\section{Guidelines for Teletandem Project}

\section{AMIGOS DE CHILE}

Read the guidelines you need to follow when developing your Teletandem Project "AMIGOS DE CHILE." You will also need to complete some tasks in each session and to report following the criteria described below.

Partners and establishing communication:

1. Your instructor will assign you to a student-partner(s) from Universidad de Concepcion in Chile.

2. Communicate with your student-partner(s) as soon as possible to exchange information such as Skype names and emails.

3. Report to your instructor the first Skype meeting you will have. Copy your instructor in the email sent to your student-partner. If your communication is through Facebook, copy your instructor in the email. In the message to your instructor, you should include the date and time of the first session you have scheduled with your student-partner.

4. Report your instructor any problem you have communicating with your student-partner. Ex: your student-partner doesn't respond to your emails, or his/her email is not working. You should establish the first contact five days after receiving the information on your student-partner.

\section{Video sessions:}

Sessions should be using a video conference format. You can use the video program of your preference (Skype, Google Hangouts or any other of your choice). The session should follow the criteria below:

1. You should use video and voice in your meeting. Sessions with only written chat are not allowed or accepted.

2. You have to record each video session ( 15 minutes in Spanish and 15 minutes in English-both students speaking the same language at a time) and upload a copy in the corresponding Dropbox in D2L. You should title each session following the format: last name, session number, and language. Ex: Smith-S1English or Smith-S1-Spanish. 
3. Each session should last at least one hour. At the same time, the conversation should be in both languages focusing on one language at a time. Ex: First 30 minutes only English and the other $\mathbf{3 0}$ minutes only Spanish. ! Your instructor will not accept session where languages are alternated! Ex: You are speaking only Spanish, and your partner is speaking only English. I recommend negotiating with your partner which language use first and talk just in that language for 30 minutes. Keep track of the time so you can switch languages after 30 minutes (if your session is one hour). For more extended sessions, divide the time equally between both languages.

4. After finishing your session, upload it to Dropbox in D2L following the criteria explained before.

5. !DO NOT EDIT YOUR SESSION! Your instructor will not accept edited sessions, and she will deduct points from your Teletandem Project.

6. All Video Sessions should be turning in in Dropbox following the session number and topic. Ex: Session 1-La Inmigración

7. The video session should address the problem (s) selected for each session and any other item chosen from the additional list.

Topics:

Each session has a specific theme and other additional talking points. Talk about the topics selected for each session and discuss any different topic of your interest. Negotiate with your student-partner which additional subject (s) to talk about in each session.

\section{Sesión 1:}

Tema 1: La inmigración en Latinoamérica y Chile. Compara la inmigración en Chile contra la inmigración en Estados Unidos. Pregunta toda la información que puedas sobre el tema de la inmigración y crea tus propias preguntas.

Tema 2: Escoge uno de los Temas Adicionales y discútelo con tu compañero/a.

\section{Sesión 2:}

Tema 1: El machismo y la violencia de género en Chile. Compara el machismo y la violencia de género en Chile contra la violencia de género en Estados Unidos. Pregunta toda la información que puedas sobre el tema del machismo y la violencia de género y crea tus propias preguntas. 
- | Teaching social issues through cinema and teletandem

Tema 2: Escoge uno de los Temas Adicionales y discútelo con tu compañero/a.

\section{Sesión 3:}

Tema 1: El Narcotráfico en Latinoamérica. Compara el narcotráfico en Chile contra el narcotráfico en Estados Unidos. Pregunta toda la información que puedas sobre el tema del narcotráfico y crea tus propias preguntas.

Tema 2: Escoge uno de los Temas Adicionales y discútelo con tu compañero/a.

\section{Sesión 4:}

Tema Abierto

\section{Temas Adicionales:}

1. La Música

2. El Cine

3. El Arte

4. La Educación o el Sistema Educativo (Elementary, Middle and High School)

5. La Vida Universitaria

6. Las Festividades

7. La Comida

8. Cosas para hacer en la ciudad

9. La Familia

10. Sitios Turísticos importantes de Chile

11. Viajando por Chile

12. El Matrimonio

13. La historia del País

14. Los indígenas y las comunidades indígenas en su país.

15. Las Tradiciones

16. El trabajo y las oportunidades de trabajo.

17. Las diversiones.

18. Cómo es la vida diaria de un chileno.

19. Tecnología

20. La Industria 